Serwatka, A. (2018). Accelerators for startups in Europe. Copernican Journal of Finance \& Accounting, 7(1), 67-81. http://dx.doi.org/10.12775/CJFA.2018.005

\author{
Anna Serwatka* \\ AGH University of Science and Technology \\ Jagiellonian University in Kraków
}

\title{
ACCELERATORS FOR STARTUPS IN EUROPE
}

Keywords: startup, accelerator, incubator.

J E L Classification: M13, N20, N24.

\begin{abstract}
According to Steve Blank, a startup is a temporary organization that is looking for a profitable, scalable, and repeatable business model. The aim of this article is to compare the startup environments in Poland and other European Union countries, in particular the functioning of accelerators and incubators. The study is based on analysing the sources of acceleration programs and methods of supporting young companies. It turns out that since 2007, the economies of European countries and the US have been feeling the growth of small enterprises that are innovative, and their products are often revolutionizing global markets. Many startups also end up in bankruptcy, but this does not discourage entrepreneurs from creating more and more new teams work on new innovative technologies. One of the biggest problems for start-up companies is finding financing. Hence the interest in the acceleration programs, thanks to which companies gain financing and, above all, mentoring and contact with investors and customers. The effects of cooperation between accelerators and young companies can also be seen on the Polish market. In the last two years new government projects have been created and directed by large corporations, which are supporting the ideas of young people and encourage the development of startups.
\end{abstract}

Date of submission: May 21, 2018; date of acceptance: June 5, 2018.

* Contact information: aserwatka@agh.edu.pl, AGH University of Science and Technology, Czarnowiejska 70, 33-332 Kraków, Poland, phone: 511166 923; ORCID ID: http://orcid.org/0000-0002-0279-1630. 


\section{INTRODUCTION}

Small startups have become very popular in recent years (Ries, 2017). But what is a startup? There are many definitions of this phenomenon, for example in Business Dictionary we read that a startup is an early stage in the life cycle of an enterprise where the owner moves from the idea stage to securing financing, laying down the basis structure of the business, and initiating operations or trading. Adora Cheung, cofounder and CEO of Homejoy, said in an amusing, but true way, that startup is a state of mind.

Though Silicon Valley is home to the largest cluster of startups, startups are created all over the world. Governments of many countries are trying to make it easier for small businesses to form. There are many programs and accelerators that give opportunities for development for beginner businesses (Cremades, 2016). One of many opportunities for a startup is participation in an accelerator. How does an accelerator work? The idea of the accelerator is quite simple. The organizers accept a group of young startups who, for a fixed time (usually no longer than six months) take part in intensive workshops. During the workshops, the startups liaise with experts, entrepreneurs operating in the same industry, and prospective investors. Organizers and investors can invest in startups in exchange for a small percentage of shares in the company (Dempwolf, 2014). According to a report published in South By Southwest, the 15 best startup accelerators in the United States are Y Combinator, TechStars, AngelPad, Launchpad LA, MuckerLab, AlphaLab, Capital Innovators, Tech Wildcatters, Surge Accelerator, The Brandery, Betaspring, BoomStartup, Entrepreneurs Roundtable Accelerator, JumpStart Foundry and DreamIt Ventures. The best European accelerators are Seedcamp, MassChallenge Switzerland, Wayra, Startupbootcamp, NEXT.amsterdam, Beta-I, NUMA, NDRC, Startup Sauna and Accelerace. In this article we will focus on accelerators in Europe.

\section{THE RESEARCH METHODOLOGY, HYPOTHESES}

\section{AND THE COURSE OF THE RESEARCH PROCESS}

The article uses national and foreign literature on the subject to discuss the issue of financing young companies. At the beginning, basic concepts such as startup, incubator and accelerator were defined. Accelerators in Poland and other European countries have been characterized and compared. The data provided by PARP was analyzed. The aim of the article is to answer the follow- 
ing two questions: is the Polish market keeping up with global trends? How does the Polish government support young companies? The hypotheses we put forward are that Poland is opening up to solutions that have already been implemented in European countries and the USA, and the government through acceleration programs opens new paths for startups.

\section{Startup EnVironment in Poland}

The development of startups and accelerators has not bypassed Poland. The Startup Poland foundation collected the results of its research in the report "Polish startups 2017", which shows that the Polish economy is open to new projects. Year after year, more and more startups in Poland are forming. It is interesting to note the results regarding the age of startup founders outnumber those aged $30-39$ (58\%), while $26 \%$ of managers are under 30 years of age (graph 1).

Graph 1. The age of the founder

\section{The age of the founder}

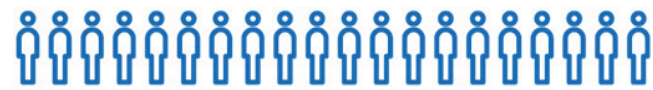

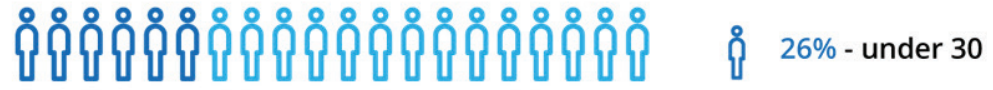

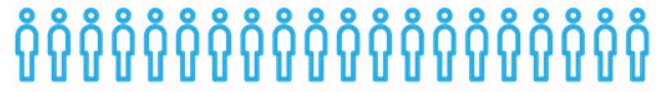

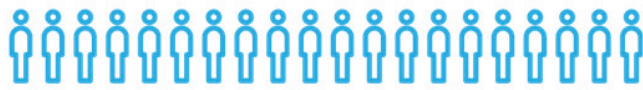

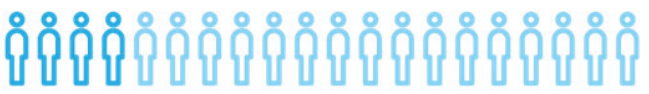 \\ $58 \%-30-39$ \\ $16 \%$ - over 40}

S o u r c e : own study based on: PARP, 2017, p. 14.

The idea for a good business is just the beginning of a startup. The biggest problem for young entrepreneurs is of course getting financing (especially in the first stage of product development). Although about 62 percent of startups finance their businesses with their own savings, entrepreneurs often search 
for external financing. The most popular source of external capital is venture capital, then public money from EU funds (PARP or NCBiR), business angels and money obtained from acceleration programs (graph 2).

Graph 2. Sources of external capital

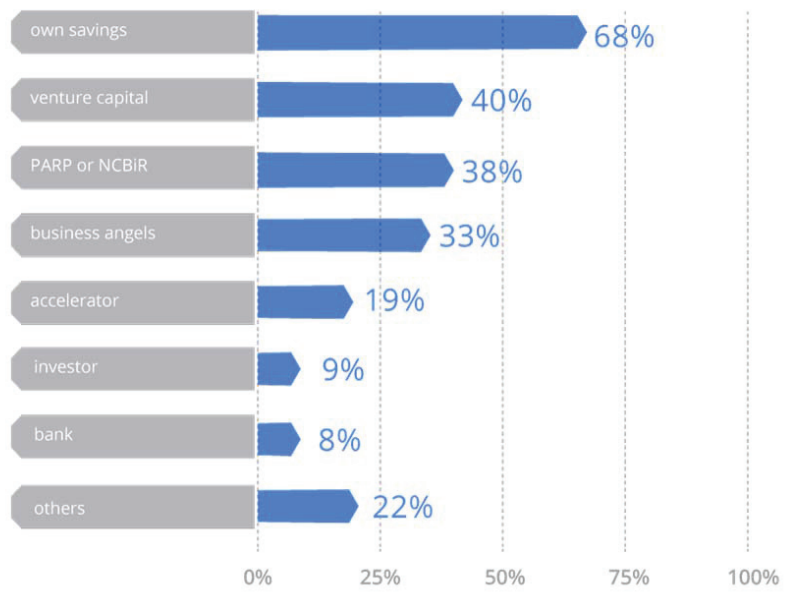

S o u r c e : own study based on: PARP, 2017, p. 26.

We need to differentiate between different models and business strategies. In particular, the B2B (Business to Business) model means the relationship between companies (ie between the company and partners, agents, suppliers, distributors) and B2C (Business to Customer), which means the relationship between the company and the customer on the retail market. In Poland, 76 percent of startups operate in the B2B model, that is, selling technologies and services to other companies, while other startups have opted for the B2C model. Warsaw, Wrocław, Kraków, Poznań and Gdańsk are cities in Poland where the most startups are established.

\section{ACCELERATORS IN POLAND}

The Polish market offers startups many accelerators and incubators. Among the initiatives from recent years is the "Ready to Go!" (RTG!) Program, run by AIP Business Link (a network of accelerators for business), which operates 10 offices in the largest Polish cities. Thanks to Ready to Go, Polish startups 
have the opportunity to participate in acceleration programs in Silicon Valley, Shanghai, and London.

In Poland, accelerators created by large international IT or telecommunications corporations are still being created, for example Hubraum in Cracow and Orange Fab in Warsaw. Hubraum is the incubator of Deutsche Telekom, and since 2012 has three locations: Berlin, Krakow, and Tel-Aviv. Hubraum offers comprehensive support in four areas: financing, providing space to work (the possibility of co-working), consulting mentors and experts, and access to Deutsche Telekom's resources (such as customer base, technical services, access to infrastructure). Orange Fab offers 12 weeks of work on the implementation of the pilot project, the possibility of scaling the product on the international market, in cooperation with foreign Orange Fab, expert support, coworking space in the center of Warsaw and access to infrastructure, consumer research center, Orange sales network. Both accelerators focus on start-ups developing products that could broaden their range of services.

In the past few years, there have also been government-founded projects for startups. The Start in Poland program of the Ministry of Development is to help 1.5 thousand companies enter the Polish market by 2023, thus creating high-quality innovative technologies. The program consists of two stages: the incubation and acceleration stage, followed by the phase of further development or expansion on the international arena. During the congress, which took place on 15-16 June 2016 in Krakow, Mateusz Morawiecki and Jarosław Gowin, informed attendees of the launch of the acceleration program Start in Poland. The ministers indicated it would be the largest program in Central and Eastern Europe and would provide financing of almost PLN 3 billion. The money would come from public funds, specifically the Intelligent Development 2014-2020 Program (EU funds).

The most important assumptions of the program were to:

- develop the startup ecosystem in Poland,

- create a program for startups,

- open public institutions to products created by startups,

- use the potential of State Treasury companies to finance innovative polish businesses,

- support foreign development.

In the first stage of the program, the Ministry of Development, as a result of the Scale Up competition from the Start In Poland program, chose 10 Polish companies to receive a total of 60 million PLN to support startups. Repre- 
sentatives of accelerators and large enterprises participating in the competition presented projects at PARP. Experts chose projects which met the criteria of the competition to the highest degree. They presented innovative solutions, revealed a professional development plan for startups under acceleration, and showed experience in similar activities.

The following companies have been able to create an accelerator (Jeznach, 2017):

- FundingBox Accelerator Sp. z o.o.,

- Pomorska Specjalna Strefa Ekonomiczna Sp. z o.o.,

- HardGamma Ventures Sp. z o.o.,

- Fundacja Przedsiębiorczości Technologicznej,

- Huge Thing Sp. z o.o.,

- $\quad$ Łódzka Specjalna Strefa Ekonomiczna S.A.,

- Krakowski Park Technologiczny Sp. z o.o.,

- Program Pilot Maker (techBrainers Sp. z o.o.),

- Akcelerator Innowacji Przemysłowych INDUSTRYLAB,

- Akcelerator Idea Global (Ideo Sp. z o.o.).

Table 1 presents a list of companies that created accelerators in the Start in Poland program, the amount of funding they received from the government, and information about the industry from which they selected startups for their accelerators.

Table 1. Accelerators in the Start in Poland program

\begin{tabular}{|c|c|c|c|c|c|}
\hline No. & $\begin{array}{c}\text { name } \\
\text { of the accelerator }\end{array}$ & organizer & industry & $\begin{array}{c}\text { co-financing } \\
\text { for a single startup }\end{array}$ & $\begin{array}{c}\text { total } \\
\text { grant amount }\end{array}$ \\
\hline 1 & $\begin{array}{l}\text { GammaRebels } \\
\text { powered by Poczta } \\
\text { Polska }\end{array}$ & $\begin{array}{l}\text { HardGamma Ventu- } \\
\text { res \& Poczta Polska }\end{array}$ & $\begin{array}{l}\text { digitalization of } \\
\text { post offices, opti- } \\
\text { mization of work } \\
\text { and logistics }\end{array}$ & up to $200000 \mathrm{PLN}$ & 5859275 PLN \\
\hline 2 & $\begin{array}{l}\text { Space3ac Intermo- } \\
\text { dal Transportation }\end{array}$ & $\begin{array}{l}\text { Pomorska Specjal- } \\
\text { na Strefa Ekono- } \\
\text { miczna }\end{array}$ & $\begin{array}{l}\text { transport and } \\
\text { space sector }\end{array}$ & up to 200000 PLN & 5900000 PLN \\
\hline 3 & Impact_Poland & $\begin{array}{l}\text { FundingBox Acce- } \\
\text { lerator }\end{array}$ & $\begin{array}{l}\text { agro-food sector } \\
\text { and the health } \\
\text { care sector }\end{array}$ & up to 222000 PLN & 5695990 PLN \\
\hline 4 & $\begin{array}{l}\text { MIT Enterprise } \\
\text { Forum Poland }\end{array}$ & $\begin{array}{l}\text { Fundacja Przedsię- } \\
\text { biorczości Techno- } \\
\text { logicznej }\end{array}$ & $\begin{array}{l}\text { fintech, energy, } \\
\text { raw materials, } \\
\text { health }\end{array}$ & up to $200000 \mathrm{PLN}$ & 5900000 PLN \\
\hline 5 & ScaleUP KPT & $\begin{array}{l}\text { Krakowski Park } \\
\text { Technologiczny }\end{array}$ & smart city, IloT & up to 200000 PLN & 5899996 PLN \\
\hline
\end{tabular}


Table 1. Accelerators in the Start in Poland program

\begin{tabular}{|c|c|c|c|c|c|}
\hline No. & $\begin{array}{c}\text { name } \\
\text { of the accelerator }\end{array}$ & organizer & industry & $\begin{array}{l}\text { co-financing } \\
\text { for a single startup }\end{array}$ & $\begin{array}{c}\text { total } \\
\text { grant amount }\end{array}$ \\
\hline 6 & Startup Spark & $\begin{array}{l}\text { Łódzka Specjalna } \\
\text { Strefa Ekonomiczna }\end{array}$ & $\begin{array}{l}\text { ogistics, optimiza- } \\
\text { tion, e-commerce } \\
\text { in } \\
\text { the cosmetics, } \\
\text { automotive and IT } \\
\text { industries }\end{array}$ & up to 160000 PLN & 5530074 PLN \\
\hline 7 & Huge Thing.vc & $\begin{array}{l}\text { Huge Thing with } \\
\text { Alior Bank }\end{array}$ & $\begin{array}{l}\text { blockchain, biome- } \\
\text { trics, authentica- } \\
\text { tion and } \mathrm{Al}\end{array}$ & up to 45000 EUR & 5772449 PLN \\
\hline 8 & $\begin{array}{l}\text { Akcelerator Inno- } \\
\text { wacji Przemysło- } \\
\text { wych INDUSTRYLAB }\end{array}$ & $\begin{array}{l}\text { DGA S.A. and } \\
\text { H. CEGIELSKI- } \\
\text {-POZNAŃ S.A. }\end{array}$ & $\begin{array}{l}\text { bioeconomy, spe- } \\
\text { cifically specialty } \\
\text { chemistry } \\
\text { products, methods } \\
\text { of their production, } \\
\text { storage and distri- } \\
\text { bution, sustainable } \\
\text { energy, } \\
\text { natural resources } \\
\text { and waste mana- } \\
\text { gement }\end{array}$ & up to $200000 \mathrm{PLN}$ & 5505750 PLN \\
\hline 9 & IDEA Global & Ideo & $\begin{array}{l}\text { Insurtech, FinTech, } \\
\text { Internet of Things, } \\
\text { health and motori- } \\
\text { zation }\end{array}$ & up to $250000 \mathrm{PLN}$ & 5854091 PLN \\
\hline 10 & Pilot maker & techBrainers & $\begin{array}{l}\text { electricity, agri-fo- } \\
\text { od production, } \\
\text { electric bicycles }\end{array}$ & & 5881500 PLN \\
\hline
\end{tabular}

S o u r c e : own study.

The aim of the program was to combine the potential of new entrepreneurs with the infrastructure, experience and resources of large corporations, including state-owned companies. One of the best Polish accelerators is Idea Global. Companies that took part in the program received financial support of up to PLN 250,000, the opportunity to work on the design of their product and help in creating a business model under the supervision of mentors. The access to investors and companies interested in implementing new solutions provided by the accelerator was also important for startups.

The acceleration of Idea Global lasted five months and culminated with participation in Demo Day. The main headquarters of the accelerator is Rzeszów, but the startups cooperated remotely most of the time. During the organized meetings in Rzeszów, entrepreneurs participating in the program could get ex- 
pert advice and get to know other startups. Aspects of the Idea Global acceleration included:

- contacts and meetings with big business partners,

- mentors and services needed to develop the project,

- financing the project development based on a map of milestones,

- meetings with VC funds.

There were two acceleration rounds, during which Ideo supported 22 startups. Among startups from the first round of acceleration were companies from many industries, including IT, medical and insurance: BeforeYouGo, qBase.pro, Princity, Amutali supplement, eQUEST, LifeGel, Nanova, Beahive.be, Bars/Bizcraft, Essell. In the second round of the program, as part of the Idea Global accelerator, the following 12 young companies received funding: Metal oligopeptide antibiotics, Nootech, HigoSkinNatural, Navegante, PnP Systems, Sprzedajodpady.pl, Stock taking Box, Splentum, Kundi, Activy, FinAgent, KreditZero.

Graph 3. presents how the accelerator works: submission of the application, settlement of the competition (selection of the best startups), announcement of the list of accepted companies to the program, acceleration (workshops and training, meetings with mentors, creating a business model under the supervision of experts, work on the product), meetings with investors and VC, Demo Day (ending participation in the program), launching to domestic and foreign markets, finding an investor. 
Graph 3. Eight steps in accelerators

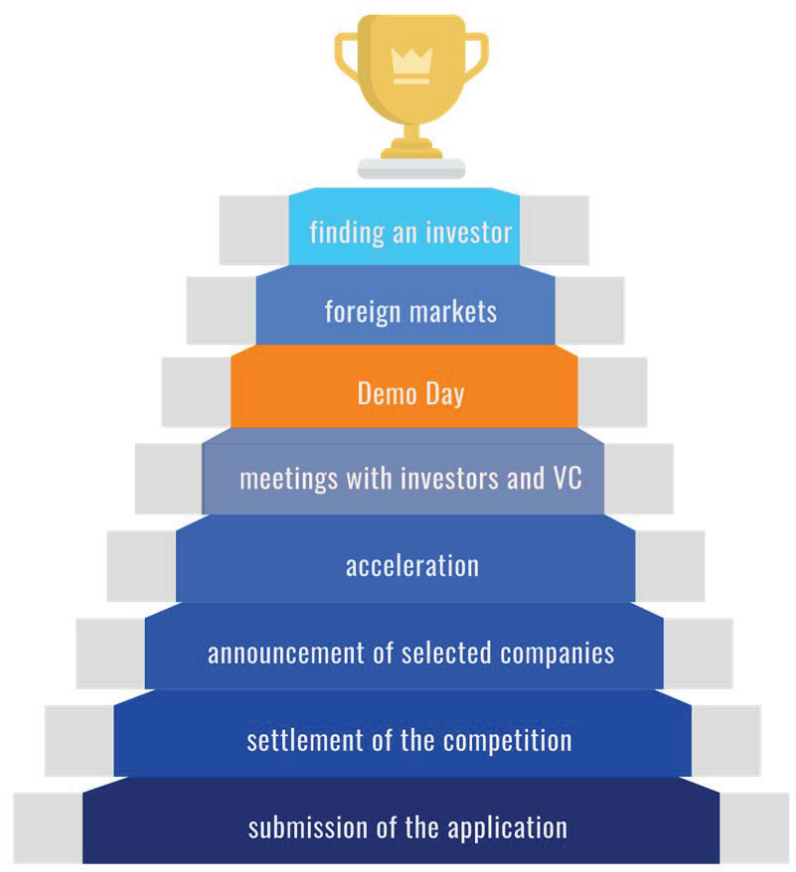

S o u r c e : own study.

\section{ACCELERATORS IN EUROPE}

Accelerators and incubators are organizations that try to help startups develop and achieve success. The concept is to provide the startup with resources, knowledge, experts, and contacts that, if well used, will accelerate its development, growth, or help in obtaining financing (Leonard, 2014). Incubators usually have their own office space, which they offer to startups. Beginning companies will find everything they need to work on their projects - desks, meeting rooms, printers and even kitchens. Accelerators provide mentoring, investment opportunities, training workshops, cooperation with other startups and companies but do not offer offices/workspace. The cooperation is based on regular meetings and remote work. The culmination of the acceleration program is Demo Day - a session during which startups present their ideas to investors 
invited by the accelerator (there is no such event in incubators). Graph 4. shows diagram of incubator and accelerator characteristics.

Graph 4. Incubator and accelerator characteristics

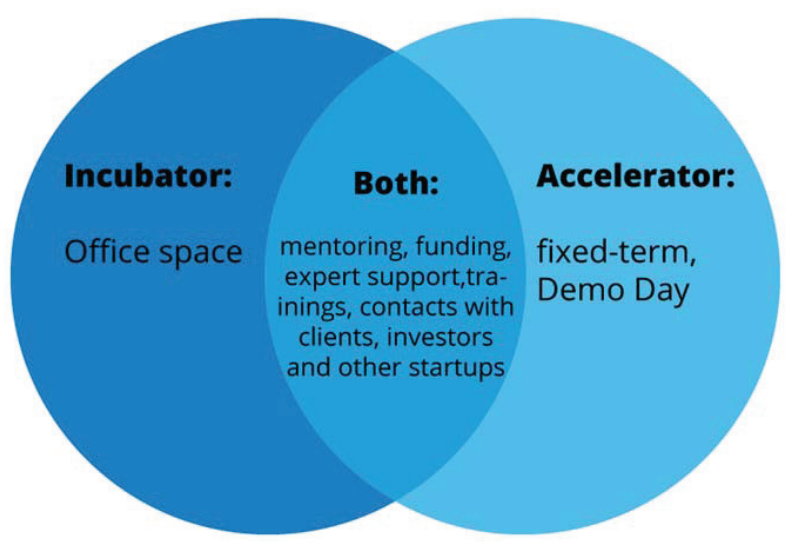

S o u r c e : own study.

Startups are not the only beneficiaries of accelerators. Business angels, venture capitals, investors also receive benefits from participating in such programs (shown in table 2).

Y Combinator, the first global accelerator for start-ups, appeared in 2005, founded by Trevor Blackwell, Paul Graham, Jessica Livingstone and Robert Morris. It's still considered one of the best. Recruitment is conducted twice a year and approximately one hundredth of companies applying are accepted. Currently, the list of startups that were in the accelerator (www1) consists of 1280 companies. Y Combinator invests small sums of money in companies (around $\$ 120,000$ ) in return for small packets of shares, but does not charge any additional fees. In addition to contacts, the company receives a "stamp" of the company that came out of the Y Combinator. 
Table 2. Who else benefits from accelerator programmes?

\begin{tabular}{ll}
\hline Angel investors & $\begin{array}{l}\text { Reduce the need for due diligence as that role performed by accelerator. } \\
\text { Reduce the cost and time required to find new companies to work with. } \\
\text { Ability to meet other investors and company founders. }\end{array}$ \\
\hline Venture capital firms & $\begin{array}{l}\text { Improve deal pipeline, creating more high quality startups. } \\
\text { Get first sight of new technology and ability to map trends in startups. } \\
\text { Ability to meet other investors and company founders. }\end{array}$ \\
\hline Large technology firms & $\begin{array}{l}\text { Talent scouting for new employees. } \\
\text { New customers for their platforms and services. }\end{array}$ \\
\hline Other startup founders & $\begin{array}{l}\text { Associate their brand with supporting new businesses. } \\
\text { Talent scouting for new employees. }\end{array}$ \\
\hline $\begin{array}{l}\text { Rapidly create a very high quality business network. } \\
\text { (e.g. accountancy firms, } \\
\text { law firms, PR firms) }\end{array}$ & $\begin{array}{l}\text { Meet customers and later-stage investors that might be relevant to their } \\
\text { businesses. }\end{array}$ \\
\hline New customers in the form of the startups the accelerators support.
\end{tabular}

S o u r c e : Bound \& Miller, 2011, p. 12.

In Europe, SeedCamp, founded in 2007 in London, is the most renowned accelerator. Its founders are Saul Klein and Reshma Sohoni. As part of this project, startups participate in acceleration programs in Great Britain and the United States. SeedCamp searches for start-ups from around the world and at the beginning invests to 200,000 euro. Later, at further stages of development, it allows further investments.

In January 2018 Arthur Gopak published the list of the best startup accelerator programs in Europe (table 3). Note that most of the accelerators listed in table 2 are in the UK (Barclays Accelerator, Bethnal Green Ventures, Distill Ventures, Emerge Education, Entrepreneur First, Startupbootcamp Insurance London and Techstars London). There are also representatives from other countries: France, Denmark, Germany, Ireland, Estonia, Italy, Lithuania, Albania, and Portugal. Investments in startups range from $0 €$ (accelerators that offer mentor support, coaching, access to investors, access to clients) up to $€ 500,000$ (Yunus Social Business Accelerator in Albania). The duration is between 2 and 8 months (Emerge Education is unlimited). 
Table 3. Accelerators in the Start in Europe

\begin{tabular}{|c|c|c|c|}
\hline Programme & Location & Investment & Duration \\
\hline 33entrepreneurs & Bordeaux, France & $€ 15,000$ & Tailored schedule \\
\hline Accelerace & Copenhagen, Denmark & $\begin{array}{l}\text { Mentoring, coaching } \\
\text { \& access to investors }\end{array}$ & $6-8$ Months \\
\hline Axel Springer Plug and Play & Berlin, Germany & $€ 25,000$ for $5 \%$ equity & 3 Months \\
\hline Barclays Accelerator & London, UK & $\$ 120,000$ & 13 Weeks \\
\hline Bethnal Green Ventures & London, UK & f 20,000 for $6 \%$ equity & 3 Months \\
\hline DCU Ryan Academy & Dublin, Ireland & $\begin{array}{l}\text { Mentoring, coaching } \\
\text { \& access to clients }\end{array}$ & 10-12 Weeks \\
\hline Distill Ventures & London, UK & $f 150,000$ & 6 Months \\
\hline Emerge Education & London, UK & $\begin{array}{l}£ 40,000- \\
£ 100,000\end{array}$ & Unlimited \\
\hline Entrepreneur First & London, UK & $\begin{array}{l}\text { f } 15,000+\text { monthly allo- } \\
\text { wance for } 8 \% \text { equity }\end{array}$ & 6 Months \\
\hline GameFounders & Tallinn, Estonia & $\$ 25,000$ & 3 Months \\
\hline The Birdhouse & Gent \& Antwerp, Belgium & $\begin{array}{l}\text { Mentoring, coaching } \\
\text { \& access to investors }\end{array}$ & 6 Months \\
\hline H-FARM & Roncade, Italy & $€ 20,000$ & 3 Months \\
\hline Lisbon Challenge & Lisbon, Portugal & $€ 10,000$ for $1.5 \%$ equity & 10 Weeks \\
\hline Rebelbio & Cork, Ireland & $\$ 250,000$ & 3 Months \\
\hline MassChallenge & Switzerland & Mentoring \& coaching & 4 Months \\
\hline Microsoft Accelerator & Berlin, Germany & Mentoring \& coaching & up to 6 Months \\
\hline NDRC LaunchPad & Dublin, Ireland & up to $€ 100,000$ & 12 to 24 Weeks \\
\hline Nextstars & Paris, France & $€ 10,000$ & 4 Months \\
\hline PANDO Ventures & Frankfurt, Germany & $\begin{array}{l}\text { Mentoring, coaching } \\
\text { \& access to investors }\end{array}$ & 12 Weeks \\
\hline $\begin{array}{l}\text { ProSienbenSat.1 Acce- } \\
\text { lerator }\end{array}$ & Berlin, Germany & up to $€ 225,000$ & 3 Months \\
\hline $\begin{array}{l}\text { Rockstart Accelerator } \\
\text { (Artificial Intelligence } \\
\text { Program) }\end{array}$ & $\begin{array}{l}\text { Hertogenbosch, The } \\
\text { Netherlands }\end{array}$ & $€ 20,000$ & 6 Months \\
\hline $\begin{array}{l}\text { Rockstart Accelerator } \\
\text { (Digital Health) }\end{array}$ & $\begin{array}{l}\text { Nijmegen, The Nether- } \\
\text { lands }\end{array}$ & $€ 20,000$ & 6 Months \\
\hline
\end{tabular}


Table 3. Accelerators in the Start in Europe

\begin{tabular}{|c|c|c|c|}
\hline Programme & Location & Investment & Duration \\
\hline $\begin{array}{l}\text { Rockstart Accelerator } \\
\text { (Smart Energy Program) }\end{array}$ & $\begin{array}{l}\text { Amsterdam, The Nether- } \\
\text { lands }\end{array}$ & $€ 20,000$ & 6 Months \\
\hline $\begin{array}{l}\text { Rockstart Accelerator } \\
\text { (Web/Mobile Program) }\end{array}$ & $\begin{array}{l}\text { Amsterdam, The Nether- } \\
\text { lands }\end{array}$ & $€ 15,000$ & 5 Months \\
\hline SeedRocket & Barcelona, Spain & $€ 150,000$ & 3 Months \\
\hline Startup Reykjavik & Reykjavik, Iceland & $\$ 23,500$ & 10 Weeks \\
\hline Startup Sauna & Helsinki, Finland & Mentoring \& coaching & 7 Weeks \\
\hline Startup Wise Guys & $\begin{array}{l}\text { Tallinn, } \\
\text { Estonia }\end{array}$ & $€ 30,000$ & 12 Weeks \\
\hline $\begin{array}{l}\text { Startupbootcamp Smart } \\
\text { City Amsterdam }\end{array}$ & $\begin{array}{l}\text { Amsterdam, The Nether- } \\
\text { lands }\end{array}$ & $€ 15,000$ for $8 \%$ equity & 3 Months \\
\hline Startupbootcamp Berlin & Berlin, Germany & $€ 15,000$ for $8 \%$ equity & 3 Months \\
\hline $\begin{array}{l}\text { Startupbootcamp Internet } \\
\text { of Things and Big Data } \\
\text { Barcelona }\end{array}$ & Barcelona, Spain & $€ 15,000$ for $8 \%$ equity & 3 Months \\
\hline $\begin{array}{l}\text { Startupbootcamp HighTe- } \\
\text { chXL Eindhoven }\end{array}$ & $\begin{array}{l}\text { Eindhoven, The Nether- } \\
\text { lands }\end{array}$ & $€ 15,000$ for $8 \%$ equity & 3 Months \\
\hline $\begin{array}{l}\text { Startupbootcamp Singapo- } \\
\text { re (FinTech) }\end{array}$ & Singapore & $€ 15,000$ for $8 \%$ equity & 3 Months \\
\hline $\begin{array}{l}\text { Startupbootcamp Insuran- } \\
\text { ce London }\end{array}$ & London, UK & $€ 15,000$ for $8 \%$ equity & 3 Months \\
\hline StartupHighway & Vilnius, Lithuania & $€ 25,000$ & 13 Weeks \\
\hline Techstars London & London, UK & $\begin{array}{l}\$ 20,000 \text { for } 6 \% \text { equity }+ \\
\$ 100,000 \text { convertible note }\end{array}$ & 3 Months \\
\hline $\begin{array}{l}\text { Yunus Social Business } \\
\text { Accelerator }\end{array}$ & Tirana, Albania & $\begin{array}{l}\text { up to } \\
€ 500,000\end{array}$ & 4 Months \\
\hline
\end{tabular}

S o u r c e : Gopak, 2018.

According to Venionaire Capital European accelerators are characterized by a mix of private and public funding. Berthold Baurek-Karlic said that in 2017 $27 \%$ of European accelerators reported either a mixed funding or a $100 \%$ public funding (Venionaire Capital, 2017). 


\section{ConCLUSION}

In Europe, and the United States, there is still an increase in the number of accelerators, incubators and startups using these programs. Accelerators are funded by large companies, investors as well as governmental and European Union money. Although Polish accelerators are not yet included in the lists of leading global accelerators, the development of such organizations and programs on the Polish market is also noticeable.

Polish and foreign accelerators have the same acceleration scheme. Depending on the program, they offer financial support at various levels. All projects offer expert support and enable contacts with investors and clients. It can be seen that the Polish market is trying to catch up with the world leaders, hence the government programs supporting the development of Polish companies and the pressure of corporations to look for innovative and modern solutions.

The article answers the previously asked questions. We are observing the development of the startup environment in Poland, among others thanks to such programs as Start in Poland. Although we are still far from the world leaders, the increase in the number of startups and their successes on the Polish market is visible and maintains an upward trend.

\section{REFERENCES}

Bound, K., \& Miller, P. (2011). The Startup Factories The rise of accelerator programmes to support new technology ventures, http://businessincubation.com.au/wp-content/uploads/StartupFactories-Accelerators-Evaluation-NESTA-June-2011.pdf (accessed: 13.04 .2018$)$.

Cremades, A. (2016). The Art of startup fundraising. Hoboken: John Wiley \& Sons.

Dempwolf, C. (2014). Innovation Accelerators: Defining Characteristics Among Startup Assistance Organizations. Optimal Solutions Group, LLC College Park, MD 20740.

Gopak, A. (2018). Best startup accelerator programs in Europe, http://www.alphagamma.eu/entrepreneurship/best-startup-accelerator-programs-europe (accessed: 13.04.2018).

Jeznach, M. (2017). Start in Poland, http://startuppoland.org/znamy-10-akceleratorow-ktore-powstana-w-ramach-start-in-poland (accessed: 13.04.2018).

Leonard, J. (2014). Startup Incubators and Business Accelerators: The Easy Way to Create a Startup Incubation and Business Acceleration Center.

Nielsen, N.H. (2017). Startup funding. 
PARP (2017). There is talent. There is capital. Start in Poland, http://www.parp.gov. pl/images/PARP_publications/pdf/2018_broszura_start_in_poland.pdf (accessed: 15.04.2018).

Ries, E. (2017). Summary - The Lean Startup. Createspace.

Venionaire Capital (2017). Top 20 European Accelerators of 2017, http://www.venionaire.com/european-accelerators-2017 (accessed: 15.04.2018).

(www1) Y Combinator Company List, http://yclist.com (accessed: 15.04.2018). 